\title{
Poverty and Disability
}

A critical review of the literature in low and imiddle-income countries

By Prof Nora Groce, Dr Gayatri Kembhavi, Prof Shelia Wirz, Dr Raymond Lang, Dr Jean-Francois Trani, Dr Maria Kett.

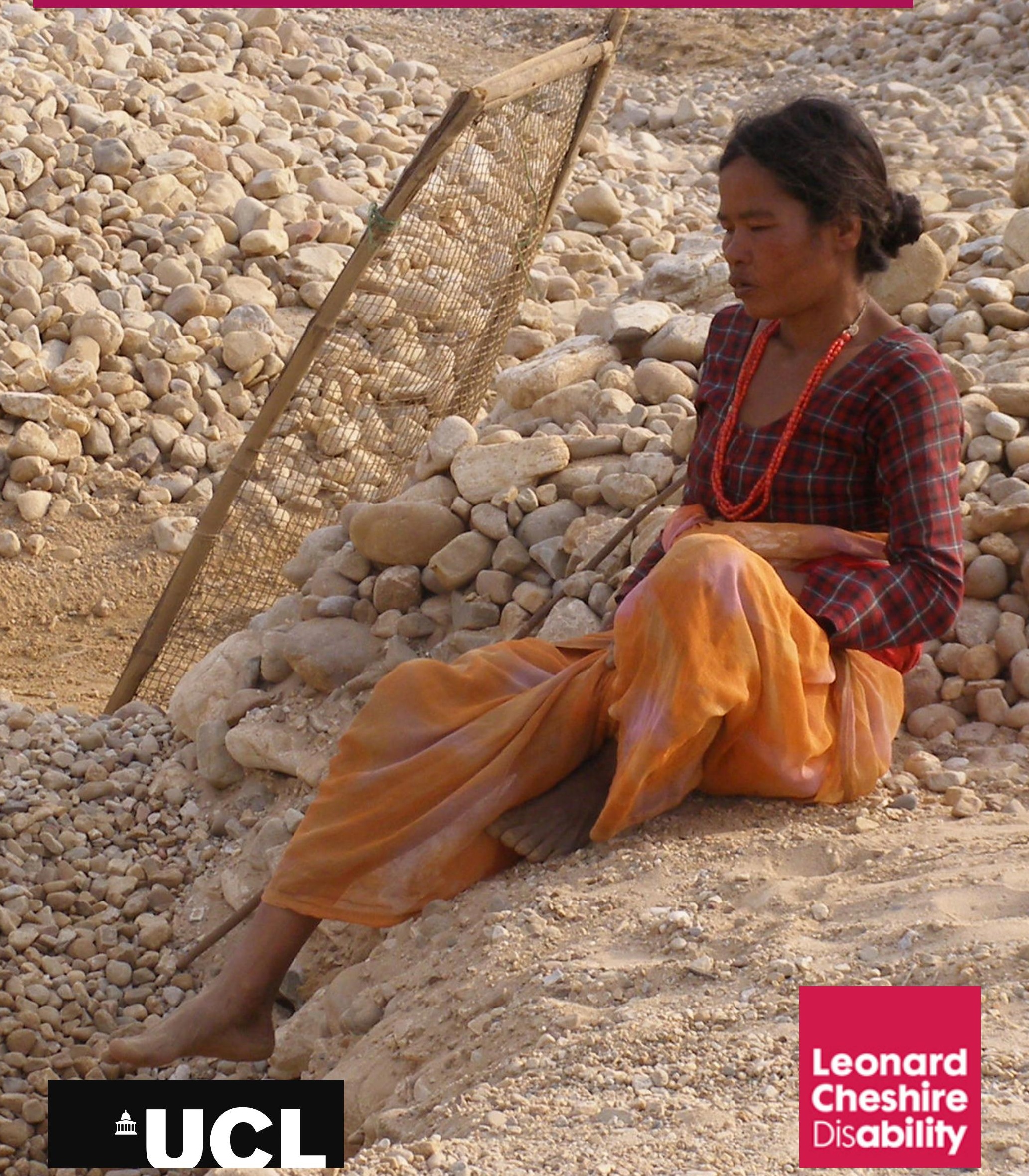




\section{Leonard Cheshire Disability and Inclusive Development Centre}

Poverty and disability - a critical review of the literature in

Low and Middle-Income Countries

September 2011

Nora Groce, ${ }^{*}$ Gayatri Kembhavi,

Shelia Wirz, Raymond Lang, Jean-Francois Trani, Maria Kett.

Working Paper Series: No. 16

*Corresponding author: Professor Nora Groce nora.groce@ucl.ac.uk

Full Working Paper Series

http://www.ucl.ac.uk/lc-ccr/centrepublications/workingpapers 


\section{ABSTRACT}

While it is widely assumed that disability, poverty and health are closely linked, this is the first critical review on the subject that explicitly asks: 'What is the current evidence base for the link between poverty, disability and health in low- and middle-income countries? The methods used have been adapted from the EPPI Centre (EPPI-Centre, 2007) and the work of Greenhalgh (Greenhalgh, Robert, Macfarlane, Bate, Kyriakidou, \& Peacock, 2005) A total of 964 papers were identified and, of these, 293 were selected for further review based on appropriateness of fit. An initial review of the 293 papers, paying particular attention to those papers that presented an evidence base, found only 27 papers $(9.2 \%$ of total papers reviewed) met the established inclusion criteria for a critical review. Widening these inclusion criteria did not produce significantly more evidence based papers for review. Thus, the most significant finding from this study is the current lack of strong evidence on the links between disability, poverty and health in LMICs upon which to build global policy and programming. Within the group of papers available for review, we identify a small but growing evidence base that indicates that there are substantial links between disability, poverty and health; however emerging research indicates that these links are more complex and nuanced than is currently assumed. We conclude with a call for more attention to building an evidence base on the interactions between disability, poverty and health. The absence of a robust evidence base that explicitly links these issues, in conjunction with the lack of appropriate benchmarks and indicators to measure disability rights commitments (including poverty reduction), will otherwise result in a "democratic deficit".

\section{ACKNOWLEDGEMENT}

This document is an output from the Cross-cutting Disability Research Programme funded by the UK's Department for International Development (DFID). The views expressed are those of the authors and do not necessarily represent those of DFID.

Published by the Leonard Cheshire Disability and Inclusive Development Centre, University College London (UCL). 


\section{INTRODUCTION}

This paper critically reviews and synthesises the currently available evidence base regarding the relationship between disability, poverty and health. While it is widely asserted that disability and poverty are closely linked, this is the first review that explicitly asks: 'What is the current evidence base for the link between disability, poverty and health in low-and middle-income countries?'

The methods used have been adapted from the EPPI Centre (EPPI-Centre, 2007) and the work of Greenhalgh (Greenhalgh et al., 2005), with the focus on qualitative and quantitative articles published in the peer-reviewed literature. While we recognise that additional papers and reports exist in the 'grey' or non-peer reviewed literature, this particular study adheres to the criteria for critical reviews, focusing on evidence bases papers in the peer reviewed literature.

Establishing a firm evidence base for the links between disability, poverty and health has taken on added significance with the new UN Convention on the Rights of Persons with Disabilities (UNCRPD) (United Nations, 2006) as disability issues are now being brought into the mainstream of development policy and practice. This opportunity must not be wasted - it is imperative that initiatives to bring people with disabilities into broader development programmes be based on accurate information.

Over the last decade, a handful of statistics on the relationship between disability and poverty have been used repeatedly, and their relationship to ill health has been routinely assumed to be strong within the global health literature. However, a careful review of the robustness of evidence, undertaken at the outset of this study, revealed significant questions as to the original source and accuracy of papers to which evidence is attributed. The regular citation of these statistics by UN agencies, NGOs, disabled peoples organisations (DPOs) and governments has established what the researcher Murray Strauss has called 'evidence by citation' (Strauss, 2007), but do not stand up to rigorous analysis.

In undertaking this study, initial searches using 'disability', 'poverty' and 'health' and a series of related terms, were made in six leading databases routinely used in international development, global health and medicine. A total of 964 papers were identified and of these, 293 were selected for further review based on appropriateness of fit. An initial review of the 293 papers, paying particular attention to those papers that presented an 
evidence base, found that only 27 papers ( $9.2 \%$ of total papers reviewed) met the established inclusion criteria for a critical review. Broadening the initial inclusion criteria did not produce significantly more evidence based papers for review.

This paper presents findings from our critical review, and a discussion of those themes that emerge from the small evidence based sample we found. However, our most significant finding is the current lack of strong evidence on the links between disability poverty and health - evidence which is needed to build effective international development policy and global health programming. We also note the existing small but growing evidence base that indicates that while there are substantial links between disability, poverty and health, these links are more complex and nuanced than is currently assumed (Barron and Ncube 2010; Groce et al. 2011). This is the first critical review of the peerreviewed, published literature which examines the evidence base and synthesises the existing literature regarding the relationship between disability, poverty and health in order to answer the following questions:

1. What is the evidence that demonstrates a link between disability, poverty and health in LMICs?

2. What does this evidence tell us of the types of relationships that exist between disability, poverty and ill health?

Specifically, this review identifies published literature in peer-reviewed journals which addresses the links between disabilities, poverty and health in LMICs; examines the nature of, and causal link between, disability, poverty and health in the peer reviewed literature; identifies gaps in existing knowledge and suggests directions for future research.

\section{BACKGROUND}

That strong links exist between disability, poverty and health is a source of unquestioned concern in the international development and global health communities. The idea that poverty is both cause and consequence of disability has been argued by numerous authors (Elwan,1999,Zimmer 2008; Parnes, 2009). Many components of this link have already been explored in the established social science literature: poor living conditions, unsafe working environments, poor nutrition, lack of access to clean water, basic sanitation and nutritious food, health care and education, all disproportionately impact the poor and can result in disability. An individual who is born with a disability or who 
becomes disabled often faces social marginalisation and has significantly less chance of accessing health care, education, or employment leading to poverty, which in turn results in restricted access to safe housing and food, health care and so forth. (Trani et al. 2010; Groce et al. 2011) This poverty and entrenched social exclusion affects not only the individual, but also the family as a whole. The links between disability, and poverty and health are of note, not only because they are assumed to be strong, but also because the estimated size of the global disability population - over one billion people or $15 \%$ of the world's population (WHO/World Bank:2011).

Attention to disability within the international development community is increasing through a series of current activities with a major catalyst being the new UN Convention on the Rights of Persons with Disabilities (UN, 2006), which establishes the equal inclusion of persons with disabilities in all development and global health efforts as a 'right', as well as new initiatives within the UN to incorporate people with disabilities into all current and future Millennium Development Goal (MDGs) efforts (United Nations, 2009). This focus on poverty reduction is a foundational goal of the new WHO guidelines on communitybased rehabilitation (WHO, 2010) and attention to poverty in the new WHO/World Bank World Report on Disability. (WHOMorld Bank, 2011)

Bilateral and multilateral donor agencies are also beginning to recognise the necessity of addressing disability issues in efforts aimed at significantly reducing poverty levels and improving health. Attention to disability issues are increasingly being seen in the policies and programmes of bilateral agencies (DFID, 2000, 2007; Thomas, 2005), either as part of inclusive new policies in general outreach efforts, or in disability-specific initiatives, many of which are linked either implicitly or explicitly to poverty alleviation efforts or public health initiatives (US Agency for International Development (US AID), Japan International Cooperation Agency (JICA 2006), Swedish International Development Agency (SIDA), and GIZ (GTZ, 2006)).

\section{What evidence is available?}

To support this growing attention, UN agencies, governments, bilateral and multilateral organisations, NGOs and DPOs repeatedly use the same small set of statistics on disability, poverty, international development and health. (Elwan, 1999, Parnes, 2009, van Kampen, 2008).

For instance, dozens of papers and websites reference a World Bank survey of the poverty and disability literature undertaken by Ann Elwan (1999), in which Elwan is 
quoted as stating that while 1 in 10 of the world's population are disabled, 1 in 5 of the world's poor live with a disability. This has widely been interpreted to mean that persons with disabilities are twice as likely to live in poverty as non-disabled persons. However a careful reading of Elwan discloses that she herself is much more cautious about this particular statistic. In a summary of existing statistics on poverty, she states only that 'disabled people are estimated to make up 15 to 20 per cent of the poor in developing countries,' and cites the source of this statement clearly as an unpublished communication between an established disability researcher and a World Bank expert (1999:15), before going on to discuss how the evidence linking disability and poverty is not unequivocal in all cases.

Similarly, in both the peer-reviewed and grey literatures and websites from dozens of UN agencies, NGOs and DPOs (disabled peoples organisations), it is reported that $80 \%$ of disabled persons worldwide live in developing countries and $60-75 \%$ of these live in rural areas (despite the fact that over half of the global population is now urban based); $30 \%$ of all street children have some type of disability, $90 \%$ of all children with disabilities in the developing world are still not in school, global literacy rates for disabled adults are as high as $97 \%$, and unemployment rates among persons with disabilities are higher than $80 \%$ in many countries. We explored the source of these routinely cited facts and figures. The figures have been given weight and credence because they are published in UN or bilateral reviews or policy papers. Checking and verification of these statistics at their source is more problematic, generally leading to a handful of non-peer reviewed small studies or a single study, drawn either from the 'grey literature' or from UN documents.

These well-known statistics are not necessarily wrong, but they are largely unsupported. At best, they can be assumed to be currently available estimates. But they do not stand up to critical review. Part of the reason for a limited evidence base may be that little funding has been available either for disability-specific research or for the inclusion of disability issues in larger health and development studies (DESA, 2011).

In summary, regular repetition by UN agencies, NGOs, DPOs and governments has established what the researcher Murray Strauss has called 'evidence by citation' (Strauss, 2007). In light of rising interest in disability in international development and global health, it is high time to review and rethink what we actually know about the links between disability and poverty. 


\section{Clarification of Definitions}

\section{Defining Disability}

Definitions of both disability and poverty are complex. Disability is defined differently depending on the paradigm that is being considered. The medical model of disability is strongly normative, based on the individual and his or her medical condition and people are considered to be disabled on the basis of being unable or less able to function as a "normal" person (Mitra, 2006).

Conversely, the social model of disability maintains that persons are 'disabled' when the physical, cultural, political and economic structure of the society in which they live does not accommodate their impairment (Oliver,1996; Shakespeare,2001). It also addresses issues of marginalisation, exclusion, oppression and discrimination, while trying to denounce and remove the disabling barriers produced by what are defined as hegemonic social and cultural institutions. The social model, which came to prominence the 1980s championed by the global Disability Rights Movement, has formed the basis upon which a "human rights model' has been built.

It is this human rights model, with its social model underpinnings, that frames the new UNCRPD and among other components calls for the equitable inclusion of persons with disabilities in international development and global health efforts. Interestingly, the UNCRPD itself does not define disability, but rather finds that disability is an evolving concept in which:

\footnotetext{
"Persons with disabilities include those who have long-term physical, mental, intellectual or sensory impairments which in interaction with various barriers may hinder their full and effective participation in society on an equal basis with others." (Article 1).
}

The WHO, seeking a definition that encompasses both the medical and social models, has developed the International Classification of Functioning, Disability and Health (ICF) (World Health Organization, 2001), which currently is widely used by researchers and policy makers when addressing disability issues in the global development literature. In this model, disability is an umbrella term, embracing impairments, activity limitations and participation restrictions. An impairment is a limitation in physical and/or intellectual 
function; an activity limitation is a difficulty encountered by an individual in executing a task or action; a participation restriction is encountered by an individual in relation to the surrounding physical, social or cultural environment. Thus disability is a complex phenomenon, reflecting an interaction between features of a person's body and features of the society in which he or she lives. The ICF provides a conceptual framework within which changes to the environment through development efforts can mitigate the degree to which a person is functionally disabled. Within this model, minor adaptations in standard development practices - low cost, low-tech adaptations such as curb cuts in new roads or sidewalks, a ramp into classrooms, accessible water tap or latrine - can have significant implications for the health and socio-economic status of the individuals involved. Another approach to the definition of disability used by some researchers is Sen's capability approach (Mitra, 2006; Terzi, 2004), which argues that equality should be defined in terms of the capability each individual has to pursue and to achieve well-being, i.e. to pursue and enjoy states and objectives constitutive of her or his well-being (Sen,1992). Rather than trying to 'label' a person as disabled or not disabled, it focuses on whether a given impairment in an individual leads to vulnerability and barriers in functioning in contemporary society. The capability approach therefore also looks at the impact of disability on the family and community, in terms of coping strategies, resources and burden. It focuses mainly on the agency of the person to take the decisions that he or she has reason to value.

\section{Definitions of poverty}

Economists have traditionally measured poverty by the lack of income or low levels of consumption. Welfare economists and social policy makers consider the poor as those individuals whose income is below a referenced subsistence level, known as the poverty line. However, such measures fail to distinguish between income and livelihood in a cashless society. Two traditional poverty measures (the head count ratio and the income gap ratio) have been criticised by Sen because they do not take into consideration the distribution of income among the poor or the change in total poverty induced by a worsening of the situation of people already poor. Other authors argue that poverty cannot be measured by a single indicator of well-being, but that other factors such as food intake, shelter, life expectancy, education, provision of public goods must be taken into consideration (Atkinson \& Bourguignon,1982;Kolm,1977;Maasoumi,1986;Tsui,1995). 
There is also growing interest in 'multidimensional' poverty, in which poverty is not only a deprivation of income but also an insufficient coverage of various human needs (Streeten, 1981). The concept of multi-dimensional poverty raises further questions: are the poor those deprived on any dimension? Or to be designated as poor, does an individual have to be deprived on all dimensions? A minimum of dimensions of deprivation is then established to identify the multidimensional poor and to facilitate targeting of public policies.

\section{Methods}

This critical review of the literature in English differs from a systematic review in that in the absence of commonly agreed upon definitions of either disability or poverty to allow consistent points for comparison, no systematic assessment of the literature is possible (Grant \& Booth,2009). Given the limitations within the current literature (variations between articles that use the medical model verses the social/rights-based model, reliance on descriptive studies), we decided that a critical review rather than a systematic review was most appropriate (Grant \& Booth,2009). The methods used here have been adapted from the EPPI-Centre (EPPI-Centre,2007) and Greenhalgh et al. (Greenhalgh et al.,2005). The search terms used in each of the databases below were: (disab* OR handicap) AND ('developing countr* OR low income countr*) AND (poverty OR poor):

- CINAHL Plus

- ELDIS

- ERIC (Educational Resources Information Center)

- JSTOR

- PsychINFO

- PubMed

- Web of Science (Science Citation Index and Social Science Citation Index)

Quantitative and qualitative research articles published in peer-reviewed journals were included in the review. Only papers published about LMICs as defined by the World Bank (World Bank,2010) were included. Any papers written exclusively about high-income countries, programme descriptions, commentaries, opinion pieces, letters to the editor, conference proceedings, grey literature (including non-peer reviewed publications) were excluded. In addition, papers dealing with common mental disorders (e.g. anxiety, stress, depression), alcohol or drug dependency, accidents or injuries (that did not specifically 
discuss related long-term disabilities), or chronic illness or disease (e.g. heart disease, diabetes) were also excluded.

These database searches produced an initial 964 'hits' of which a 'long list' of 239 titles and abstracts were selected for review based on relevance to the review being undertaken. The long list was initially screened by two of the co-authors (GK, SW) working independently to determine which papers should be included in the final review. After reaching a consensus on the short-list of abstracts, the same authors read each article and completed a data extraction form. Reference lists of short-listed articles were used to ensure that all relevant articles were included in the review. Additional articles were also identified by reviewers if they were not found in the initial database search. Based on the information collected in the data extraction form, authors determined if the article was included in the final review. For the purposes of reliability, the other four authors $(R L, M K$, JFT, NG) each read a random selection of $10 \%$ of the articles. Any discrepancies about inclusion or exclusion from the review were discussed among the review team. The final list of articles included in the review was discussed by all authors. References were managed using EndNote X3 software and extracted information was entered into an Excel(C) spread sheet for further analysis. The data collected was then analysed and synthesised using a meta-narrative method, as described by Greenhalgh et al.(Greenhalgh et al.,2005). This is a method of systematically making sense of complex, heterogeneous, and conflicting bodies of literature. A narrative approach is used to 'summarize [the] key methods and findings'(Greenhalgh et.al,2009). This method of analysis and synthesis allows for the summary of quantitative, qualitative, and mixedmethods study designs.

\section{RESULTS}

Table 2 summarises the articles found through database searches and the final number of articles included in the long-list for review, and Figure 1 provides a summary of the final number of articles chosen for the review.

Table 2. Results of database searches

\begin{tabular}{l|l|l}
\hline Database & Hits & Articles selected \\
\hline JStor & 465 & 0 \\
\hline PsychInfo & 55 & 55 \\
\hline
\end{tabular}




\begin{tabular}{l|l|l}
\hline Eldis & 18 & 17 \\
\hline Eric & 12 & 12 \\
\hline CINAHL & 51 & 51 \\
\hline $\begin{array}{l}\text { Web of } \\
\text { Science }\end{array}$ & 164 & 123 \\
\hline PubMed & 199 & 35 \\
\hline Total & $\mathbf{9 6 4}$ & $\mathbf{2 9 3}$ \\
\hline
\end{tabular}

Figure 1: Process of Article Selection

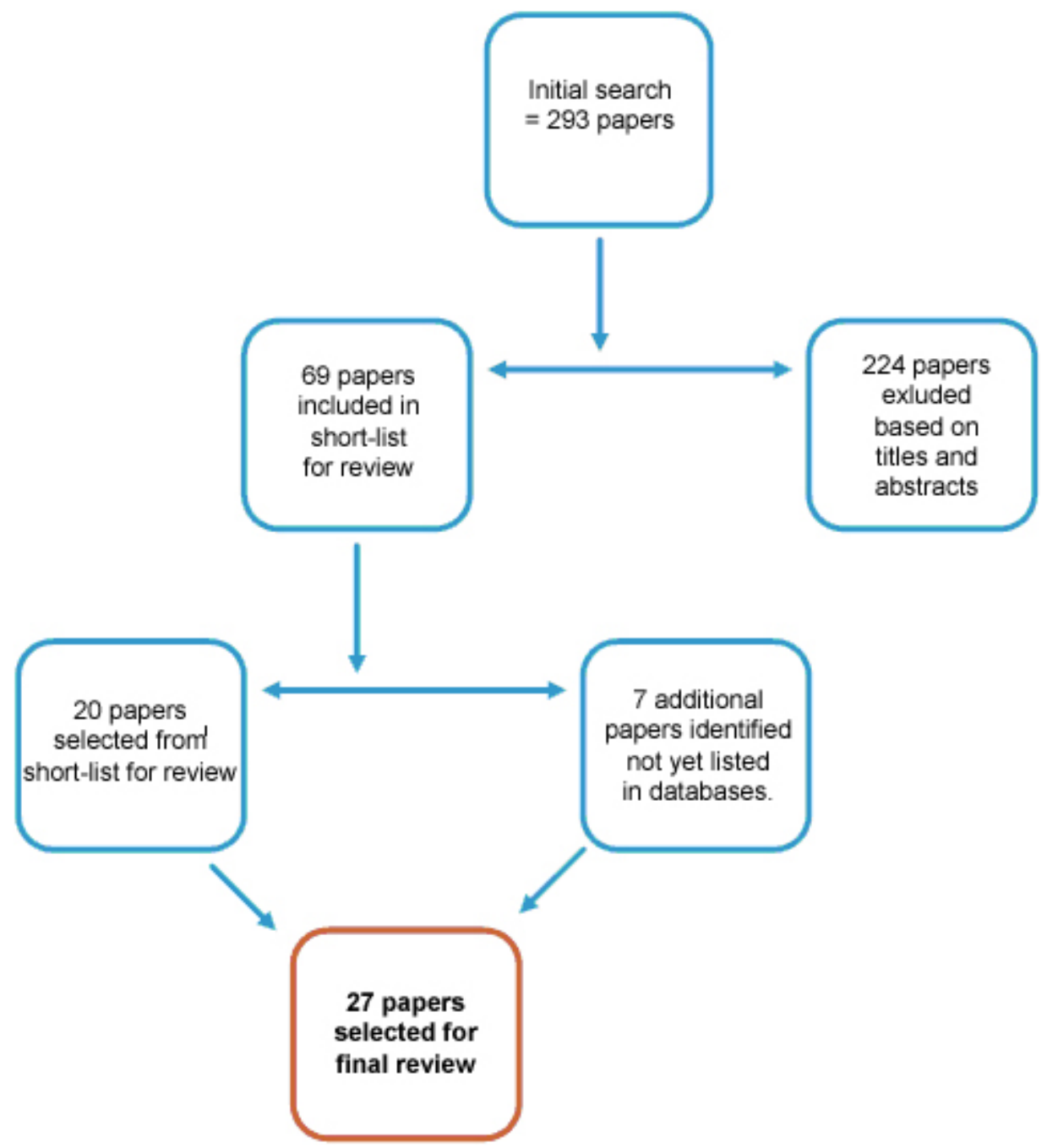

\section{Summary of articles}

Although the link between disability, poverty and health has long been asserted, the first peer-reviewed publication to address the association did not appear until 1989 (Cock,1989). Furthermore, between 1989 and 2010, only 27 published peer-reviewed research papers on this topic met our inclusion criteria. Of these 27 papers, 14 studies were conducted with the specific aim of exploring the relationship between disability and poverty (Braithwaite \& Mont,2009; Dhungana,2006; Engelbrecht \& Lorenzo,2010; 
Filmer,2008; Gureje \& Bamidele, 1999; Gureje et al, 2006; Hoogeven, 2005; Loeb et al,2008; Mitra \& Sambamoorthi,2006, 2008, 2009; Natale et al,,,1992; Rischewski et al., 2008; Trani \& Loeb, in press). The papers included in this review employed various study designs, including six qualitative research studies (Dhungana, 2006; dos Santos-Zingale \& McColl, 2006; Engelbrecht \& Lorenzo, 2010; Kiani, 2009; Schneider, Manabile, \& Tikly, 2008; Yousafzai et al,2003). The articles covered a wide geographic area, including Africa, India, Latin America, and South-East Asia. Various impairment groups were represented, including persons with physical or musculoskeletal impairments, cerebral palsy, and psychiatric or neurological illnesses (including schizophrenia and epilepsy). Not all papers specified the nature of disability included in their samples. Appendix I chronologically summarises the articles included in the review. ${ }^{1}$

\section{Key themes}

Using the meta-narrative methodology, the key findings from each article were reviewed independently by each co-author and a list of common themes produced. These themes were then discussed by all reviewers to reach consensus. The key themes that emerged were:

- Disability and economic (or income-based) poverty

- Disability and multi-dimensional poverty

- Compounding factors - for example, health, type of impairment, gender, age and aging.

Each of these three main themes will be discussed and the findings presented below.

Disability and economic or income poverty

For the purposes of this paper, economic or income poverty is measured by levels of household income or assets, type of housing, or per capita consumption expenditure. Monetary or economic poverty can be conceptualised in absolute or relative terms, depending whether estimates are made in comparison to a subsistence income level or to

\footnotetext{
1 Appendix II containing the full bibliography of the 293 articles screened by title and abstract is available on the Leonard Cheshire Centre for Disability and Inclusive Development Website:: < http://www.ucl.ac.uk/lcccrl>.
} 
an average income in a given context. Absolute or extreme poverty can be defined as the economic incapacity of an individual to satisfy basic needs such as food, clothing, shelter, health care, and education. This absolute level of poverty differs from one country to another, and sometimes within a country itself, depending on the methods of calculating the annual average cost of the basic necessities for an adult to function. These are, in general, typical measurements of subsistence living. In population surveys, relative poverty can also be reported in quintiles comparing various levels of economic wealth in a country and absolute poverty by estimating the number of people living on less than the international poverty line fixed at \$1.25US in 2005 (World Bank, 1990; Ravallion, Chen, \& Sangraula,2009).

Thirteen of the 27 reviewed articles discussed the relationship between disability and economic poverty (Braithwaite \& Mont,2009; Chatterjee et al,2009; Filmer, 2008; Gureje \& Bamidele, 1999; Gureje et al., 2006; Hoogeven, 2005; Khan et al,1998; Loeb et al.,2008; Natale et al.,1992; Rischewski et al.,2008; Schneider et al., 2008; Shrestha, Shrestha, \& Deepak,2009; Trani \& Loeb, in press ). Of these, seven found a positive relationship between economic poverty and disability (Braithwaite \& Mont,2009; Filmer,2008; Gureje \& Bamidele,1999; Hoogeven,2005; Natale et al.,1992; Schneider et al.,2008; Shrestha et al.,2009 ), while five did not. The seven that discussed a positive relationship between economic poverty and disability will be discussed first.

In examining household survey data from 13 LMICs, Filmer (2008) found that in eight countries, being a disabled adult is statistically significantly associated with an increase in the likelihood of being in the poorest two quintiles of the population. Much of this association was mediated by education, which will be discussed below. Braithwaite and Mont (2009) also used survey data from Vietnam and Bosnia, with a focus on an asset index and a consumption-based measure of poverty. After factoring in extra costs associated with disability, they found that the poverty rate in Vietnam for households with a disabled person was $20.1 \%$ (compared to the national average rate of $13.5 \%$ ) and in Bosnia was $30.8 \%$, compared to a national poverty rate of $19.5 \%$.

Hoogeven (2005) used survey data from Uganda to examine those households that were headed by a disabled person and found that both the incidence and the severity of poverty were worse than in those households headed by a non-disabled person. The prevalence of disability-headed households in this survey, however, was small (5\%). In a study 
conducted in rural Nepal, Shrestha et al. (2009) found that while $8.43 \%$ of the total survey population was ranked as being amongst the 'poorest of the poor' (using wealth rankings), $75.7 \%$ of people with disabilities were considered to be the 'poorest of the poor.' Not all studies used an asset index or measures of consumption to evaluate poverty. Gureje and Bamidele (1999) used social class to examine the 'social drift theory', comparing the social class of patients with schizophrenia to their fathers. Commonly, the social class of patients with schizophrenia was significantly lower than that of their fathers, often putting them into the lowest social groups. In a small epidemiological study of childhood disability, prevalence and poverty, Natale et al. (1992) used area of residence as a proxy measure of social status, and found that the lowest status families were 2.5 times more likely to have a child with a disability than those families in the next highest social status. Schneider et al. (2008) conducted a qualitative study on women with rheumatoid arthritis, and found that they incurred additional costs because of their impairment for transportation, medication, and the need for extra help with daily tasks. The data from the final two of these seven are studies more nuanced. Examining mortality rates of children with cerebral palsy, Khan et al. (1998) found that mortality rates were linked, in part, to family income. They caution, however, that the majority of the families studied were impoverished, and thus the link between childhood mortality and poverty could not be considered a definitive finding. When examining a community-based rehabilitation (CBR) programme for people with psychotic disorders in rural India, Chatterjee et al. (2009) found that poverty was frequently cited as a reason for limited access to treatment prior to the implementation of the CBR programme, and in the majority of cases, lack of money was given as the reason that patients with schizophrenia did not attend outreach clinics.

In contrast to these themes, 5 of the 13 papers found that there was no difference between people with disabilities and non-disabled people in terms of economic poverty (Filmer,2008; Gureje et al.,2006; Loeb et al.,2008; Rischewski et al.,2008; Trani \& Loeb,2011). Although Filmer (2008) found that adults with disabilities were more likely to experience economic poverty, with the exception of India and Indonesia, the data did not suggest that children between 6 and 17 years of age were more likely to live in a poorer household than non-disabled children. When looking at functional disability in aging adults in Nigeria, Gureje et al. (2006) did not find any relationship between poverty (measured by asset ownership and type of housing) and the occurrence of disability. Similarly, Loeb et al. (2008) did not find any differences in household income and disability. In fact, in some 
cases, they found that households with a people with disabilities had higher average monthly income and more possessions, possibly because the South African government now provides disability grants for a significant number of poor, disabled South Africans. Rischewski et al. (2008) also found that measures of household assets and expenditures were not significantly different between those with and without a musculoskeletal impairment. Trani and Loeb (2010) underscore this finding in their presentation of survey data from Afghanistan and Zambia. They find that poverty, as measured by an asset index, is not systematically associated with disability, nor is it a significant risk factor for disability (Trani \& Loeb,2010).

Disability and multi-dimensional poverty

The published literature now demonstrates the need to move beyond traditional economic, monetary-based measures of household expenditures, assets and income to examine poverty from a multi-dimensional perspective. The multi-dimensional aspects of poverty include a portfolio of factors, including access to education, employment, health care, and the ability to participate in social, family and political life (United Nations Development Programme,2010). Such a definition addresses not only financial poverty but also social exclusion and marginalisation amongst the poorest in any society, including people with disabilities.

Nineteen of the 27 papers examined discuss disability and multi-dimensional poverty (Baskind \& Birbeck,2005; Chatterjee et al.,2009; Cock,1989; Dhungana,2006; dos SantosZingale \& McColl,2006; Filmer,2008; Guerra, Alvarado, \& Zunzunegui, 008; Gureje \& Bamidele,1999; Gururaj et al,2008; Hoogeven,2005; Kiani,2009; Loeb et al.,2008; Mitra \& Sambamoorthi,2006, 2008, 2009; Rischewski et al.,2008; Schneider et al.,2008; Trani \& Loeb, 2010;Yousafzai et al.,2003). A common finding amongst the papers is that education, routinely denied to disabled children, is a key factor in determining poverty during adulthood for people with disabilities (Baskind \& Birbeck,2005; Cock,1989; Dhungana,2006; Filmer, 2008; Hoogeven,2005; Kiani,2009; Mitra \& Sambamoorthi,2006; Rischewski et al.,2008; Trani \& Loeb,2010). While Loeb et al.(2008) did not find any difference between people with disabilities and non-disabled people in terms of poverty, they did find that people with disabilities had a lower mean level of education. With a slightly different focus on the impact of multi-dimensional poverty, Yousafzai et al.(2003) state that poverty was given as the reason why children with disabilities did not 
attend school. Guerra et al.(2008) found that social disadvantage in childhood, including lower levels of education, was a predictor of functional disability for older men. Lack of education was also associated with poor long-term outcomes in people with schizophrenia in rural India (Chatterjee et al.,2009).

The issue of employment is closely related to education and 11 of the articles included in this review highlight the greater likelihood of unemployment among adults with disabilities than among non-disabled adults (Baskind \& Birbeck,2005; Cock,1989; Dhungana,2006; Gururaj et al.,2008; Kiani,2009; Mitra \& Sambamoorthi,2006, 2008, 2009; Rischewski et al.,2008; Schneider et al.,2008; Trani \& Loeb,in press). Mitra and Sambamoorthi (2008, 2009) present evidence of wage differentials, with adults with disabilities earning significantly less than non-disabled peers, even for similar work. In addition to education, stigma and discrimination are frequently cited as reasons for high unemployment amongst people with disabilities. In two qualitative studies with women with disabilities, participants reported on the difficulty of overcoming poverty because of lack of access to employment (Dhungana,2006; Kiani,2009). For those women who had experienced disability from childhood, a lack of access to education reduced their chances for employment in adulthood. In contrast, women who acquired their impairment during adulthood frequently lost the financial support of their spouses (if married) and their families (Dhungana,2006; Kiani,2009). Dhungana (2006) stresses the need for relevant education and training. In her study, 12 of the 30 participants had received some form of vocational training, but this was often not relevant to the opportunities available in their home village or to their hope of work (Dhungana,2006).

Fewer studies directly considered the relationship between disability and the ability to participate in social, family or political life, despite the fact that such participation has significant economic implications - e.g. the inability to marry is significantly associated with poverty. Hoogeven (2005) found that people with disabilities who headed households in Uganda were more likely to never have married or be widowed, and Kiani (2009) found that women with disabilities in Cameroon had poorer prospects for marriage. Dhungana (2006) found that women in Nepal who became disabled after marriage were often abandoned by their husbands, thus putting them at heightened risk of poverty. Stigma was found to be a major factor in preventing people with epilepsy in sub-Saharan Africa from fulfilling social roles, such as marriage (Baskind \& Birbeck,2005). Baskind and Birbeck (2005) also found evidence for abandonment by spouses because of seizures. 
Nine of the reviewed studies also reported on other factors that impact on disability and poverty including gender, category and severity of impairment, and a difference in poverty experience between rural and urban populations (Baskind \& Birbeck,2005; Dhungana,2006; Guerra et al.,2008; Gureje et al.,2006; Kiani,2009; Mitra \& Sambamoorthi,2006; Mobarak et al,2000; Trani \& Loeb, in press; Zunzunegui et al.,2009). Few of these topics have been explored in depth in the peer-reviewed literature, but some of the key findings are highlighted here. Of the nine studies, seven provided evidence that women with disabilities are more likely to be affected by poverty than men with disabilities, and that unmarried women are the most vulnerable to poverty (Baskind \& Birbeck,2005; Dhungana,2006; Guerra et al.,2008; Kiani,2009; Mitra \& Sambamoorthi,2006; Mobarak et al.,2000; Zunzunegui et al.,2009). Unmarried women with epilepsy are more vulnerable to poverty and sexual exploitation than their non-disabled peers (Baskind \& Birbeck,2005). Women with disabilities are less likely to marry (Dhungana,2006; Kiani,2009). Women disabled after marriage are also at more risk of losing the financial support of their families, and being abandoned by their spouses. All these factors place women with disabilities at a significant economic disadvantage, even in comparison to disabled men. Mitra and Sambamoorthi (2006) found that the employment rate amongst men with disabilities was three times higher than that of women with disabilities, although this may also reflect 'women's' work' being unacceptable to men.

Links between disability and poverty extend to other members of the household and had significant health implications. For example, stress in mothers of children with disabilities is negatively correlated with poverty (Mobarak et al.,2000). Researching the livelihoods of older adults, Guerra et al. (2008) and Zunzunegui et al.(2009) found that older women were more likely than older men to become impaired.

Significant evidence on the economic links between disability and health may have been missed in this review because the methodology did not permit review of papers on disability and access to health care that have implications for poverty although these publications do not have 'poverty' in their titles or abstracts. For example, Trani et al. (2010) writing on Afghanistan, found that persons with disabilities often had less access to health care, but when health care was available, they encountered higher 'out of pocket' expenses in accessing such care. 
Few studies have investigated the relationship between type of impairment and poverty, but findings from these studies are of interest. In India, Mitra and Sambamoorthi (2006) found that people with mental illness or cognitive impairments had lower levels of employment than people with speech, hearing or locomotor impairments. Trani and Loeb (2010) report similar findings from Afghanistan and Zambia, where people with cognitive or multiple impairments or mental illness were more likely to be unemployed than those with sensory impairments. Only two papers discuss the differences between living in rural and urban areas in relation to disability, poverty and health. Gureje et al.(2006) found that the prevalence of functional disability in older adults in Nigeria was highest among those that lived in urban settings, and lowest among the rural-dwelling adults. Similarly, Mitra and Sambamoorthi (2006) using survey data published in 2002 in India, found that people with disabilities in rural areas were more likely to be employed than those living in urban areas. Research in the context of LMICs about disability and poverty related to aging is relatively new and still limited. Only three studies in this review (Guerra et al.,2008; Gureje et al.,2006; Zunzunegui et al.,2009) have analysed this issue, which is of growing concern with the increasing life expectancies in many LMICs. None of these studies examined the issue of aging of people with disabilities, but did consider the risk and prevalence of impairment in older adults. In Nigeria, Gureje et al. (2006) found that the prevalence of impairments was $9.2 \%$, and that $19 \%$ of previously non-disabled older adults with disabilities who were in need of assistance, had no access to help. While Guerra et al. (2008) found that for Brazilian adults, certain factors through the life course were predictors for impairment in later life; this was not found to be the case across other countries in Latin America and the Caribbean (Zunzunegui et al.,2009). There is growing evidence that not only are older adults more vulnerable to becoming disabled, but that they are also vulnerable to poverty, thus compounding the difficulties they face.

\section{RESULTS}

The current evidence base reviewed in this paper that supports the assumed links between disability, poverty and health is strikingly thin. Unquestionably, those articles that were identified using a standard critical review methodology, although varying significantly in relation to methodology, sample size, subject and geographical location, do point to the existence of a feedback loop existing between poverty and disability and ill health. However, the evidence of causal links between disability, poverty and health has not yet 
been clearly identified within this body of research. Furthermore, at this point the causal structural inter-relationships and dynamics that fuel this cycle remain ill-defined and significantly under-researched. Very little, if any, of the research reviewed for this paper provides robust evidence of the causality of disability and poverty, and, as suggested by Filmer (2008), at this point, 'analysis of the relation between disability and economic status should be interpreted as an association and not necessarily a cause or consequence' (p.149).

One very significant challenge of analysing the link between disability and poverty and the links these have to health, is the lack of universally accepted definitions. There is no universally agreed definition of what constitutes 'disability' (WHO/World Bank 2011; Groce et al. 2011). The concept is highly context-dependent, as recognised by the International Classification of Functioning, in which the environmental and personal factors can either facilitate or inhibit activities and participation. Consequently, it is difficult to collect comparative data. This relates to disability prevalence rates and to the complex tapestry of the livelihoods of people with disabilities in developing countries, and to the households in which they are members. Dhungana (2006) notes that the prevalence rates of disability quoted by different international organisations varied between 1.5 and $10 \%$. Although many countries are now beginning to include questions on disability status in their national censuses and on large demographic and health surveys, many of these censuses and surveys still include only a limited number of questions on disability, which diminishes their utility (WHOMorld Bank, 2011)

As discussed in the Background section of this paper, similar issues apply to the definition of poverty and the collection of data in LMIC. Both poverty and disability are difficult to define and multi-dimensional in nature and their links to health status are complex. This does not imply that further research cannot enrich the evidence base regarding the dynamics and causal relationships that exist between poverty and disability. However, as emphasised by Braithwaite and Mont (Braithwaite \& Mont,2009), 'How researchers construct a variable for disability will influence the correlations they find between disability and various socioeconomic characteristics, such as poverty' (p.2).

In order to expand the evidence base that explores the causal relationship between disability and poverty, and to better analyse its intra-household dynamics, there is also a need for longitudinal studies. Such studies enable researchers to control for unobserved 
time-invariant characteristics of households that might induce bias in estimating causal relationships using only cross-sectional data.

With the changing demographic profile of LMICs, there is also an urgent need to explore the growing issue of aging, disability and health in LMICs with reference to poverty if health and social policy planning for LMICs is to be effective. (Gu et al, 2009;Liang et al.2010; Jang et al.2010) As the review indicates, there is currently very little literature about this important topic. The few papers that have been published indicate that older adults are vulnerable to disability, poverty and ill health, and that there may be a link between poverty in earlier life and disability in later life. More research however is needed in this area, with a particular focus on the needs of older adults in LMIC.

\section{CONCLUSIONS}

Without doubt, the most significant finding from this critical review is that while a small, albeit growing body of research points to a link between disability, poverty and health, the evidence base that currently exists on these linkages, is surprisingly thin. Of the 293 papers initially short-listed for the review, only 27 published research articles $(9.2 \%)$ met the established inclusion criteria for a critical review.

This critical review demonstrates the need for more robust data on disability, poverty and health. This is important for a number of related reasons. These include the fact that the UNCRPD requires States that have ratified the Convention to generate robust data in order to demonstrate their compliance with the obligations as delineated in the Articles. This will necessitate the development of indicators to enable the collection of a far more extensive and nuanced body of data on disability, poverty and health in order to produce robust evaluations, impact assessments and the inclusion of disability issues in country assistance programmes and global health initiatives.

A solid body of evidence that explicitly links disability, poverty and health is required as disability issues move up the international development and global health agendas. This is because bilateral and multilateral donor agencies still need to be convinced of the economic rationale for including disability within their core activities. A clear link will also need to be established between implementing a rights-based approach linked with poverty 
alleviation strategies. The absence of a robust evidence base that explicitly links disability, poverty and health, in conjunction with the lack of appropriate benchmarks and indicators to measure disability rights commitments (including poverty reduction), will result in a "democratic deficit". This is because civil society institutions, including DPOs, will not have the necessary benchmarks and tools to hold their governments to account for such commitments. 
Appendix I. Papers included in critical review ordered chronologically

\begin{tabular}{|c|c|c|c|c|}
\hline $\begin{array}{c}\text { First Author } \\
\text { and Date }\end{array}$ & Study Design & Setting & Sample details & Purpose \\
\hline Cock, 1989 & $\begin{array}{l}\text { Mixed } \\
\text { methods - } \\
\text { survey data } \\
\text { and qualitative } \\
\text { key informant } \\
\text { interviews }\end{array}$ & $\begin{array}{l}\text { Soweto, South } \\
\text { Africa }\end{array}$ & $\begin{array}{l}15 \text { key informant } \\
\text { interview and data } \\
\text { from a survey } \\
\text { conducted with } 88 \\
\text { adults with spinal } \\
\text { cord injury } \\
\text { (wheelchair users) }\end{array}$ & $\begin{array}{l}\text { The experiences of } \\
\text { African spinal-cord } \\
\text { injured people in } \\
\text { Soweto, arguing that } \\
\text { their lives are marked } \\
\text { by poverty and social } \\
\text { isolation. }\end{array}$ \\
\hline Natale, 1992 & Cohort study & $\begin{array}{l}\text { Tamil Nadu, } \\
\text { India }\end{array}$ & $\begin{array}{l}640 \text { families (310 } \\
\text { from lowest SES } \\
\text { and } 330 \text { from next- } \\
\text { to-lowest SES) }\end{array}$ & $\begin{array}{l}\text { Epidemiological study } \\
\text { looking at the impact } \\
\text { of small differences in } \\
\text { SES on prevalence of } \\
\text { disability }\end{array}$ \\
\hline Khan, 1998 & $\begin{array}{l}\text { Prospective } \\
\text { longitudinal }\end{array}$ & $\begin{array}{l}\text { Dhaka, } \\
\text { Bangladesh }\end{array}$ & $\begin{array}{l}92 \text { children aged } \\
16-62 \text { months } \\
\text { enrolled } \\
\text { consecutively over } \\
1 \text { yr as they sought } \\
\text { disability services; } \\
49 \text { urban and } 43 \\
\text { rural }\end{array}$ & $\begin{array}{l}\text { Natural history of } \\
\text { cerebral palsy among } \\
\text { rural and urban } \\
\text { populations of young } \\
\text { children to develop } \\
\text { long-term survival } \\
\text { strategies }\end{array}$ \\
\hline Gureje, 1999 & $\begin{array}{l}\text { Retrospective, } \\
\text { descriptive } \\
\text { study }\end{array}$ & Nigeria & $\begin{array}{l}120 \text { men and } \\
\text { women with an } \\
\text { ICD-9 diagnosis of } \\
\text { schizophrenia in } \\
\text { contact with the } \\
\text { hospital at least } 5 \\
\text { years prior to study }\end{array}$ & $\begin{array}{l}\text { Occupational, } \\
\text { residential and social } \\
\text { outcomes of people } \\
\text { with schizophrenia } 13 \\
\text { years after diagnosis; } \\
\text { difference between } \\
\text { their SES and their } \\
\text { father's SES to test the } \\
\text { social drift hypothesis }\end{array}$ \\
\hline Mobarak, 2000 & $\begin{array}{l}\text { Cross- } \\
\text { sectional } \\
\text { survey }\end{array}$ & $\begin{array}{l}\text { Dhaka, } \\
\text { Bangladesh }\end{array}$ & $\begin{array}{l}91 \text { mothers (urban } \\
\text { and rural); children } \\
\text { between 1.5-5yrs } \\
\text { with cerebral palsy }\end{array}$ & $\begin{array}{l}\text { The degree of stress } \\
\text { experience by mothers } \\
\text { of young children with } \\
\text { cerebral palsy and } \\
\text { associated factors }\end{array}$ \\
\hline
\end{tabular}




\begin{tabular}{|c|c|c|c|c|}
\hline $\begin{array}{c}\text { First Author } \\
\text { and Date }\end{array}$ & Study Design & Setting & Sample details & Purpose \\
\hline $\begin{array}{l}\text { Yousafzai, } \\
2003\end{array}$ & $\begin{array}{l}\text { Qualitative } \\
\text { study }\end{array}$ & $\begin{array}{l}\text { Dharavi, } \\
\text { Mumbai, India }\end{array}$ & $\begin{array}{l}5 \text { Focus groups } \\
\text { ( } \mathrm{N}=10,8,5,6,12 \text { in } \\
\text { each group); } 4 \\
\text { groups of carers of } \\
\text { children with } \\
\text { disabilities } \\
\text { (primarily cerebral } \\
\text { palsy) }\end{array}$ & $\begin{array}{l}\text { Cultural feeding } \\
\text { practices for disabled } \\
\text { children in order to } \\
\text { plan an intervention } \\
\text { suited to environment, } \\
\text { and improve nutritional } \\
\text { well-being of disabled } \\
\text { children }\end{array}$ \\
\hline Baskind, 2005 & $\begin{array}{l}\text { Review (non- } \\
\text { systematic) }\end{array}$ & SSA & $\begin{array}{l}\text { N/A - literature } \\
\text { review }\end{array}$ & $\begin{array}{l}\text { Review of stigma } \\
\text { associated with } \\
\text { epilepsy in sub- } \\
\text { Saharan Africa }\end{array}$ \\
\hline $\begin{array}{l}\text { Hoogeven, } \\
2005\end{array}$ & $\begin{array}{l}\text { Cross- } \\
\text { sectional } \\
\text { survey }\end{array}$ & Uganda & $\begin{array}{l}\text { National census } \\
\text { data }\end{array}$ & $\begin{array}{l}\text { Uses Ugandan census } \\
\text { data from 1991, } 1992 \\
\text { to estimate the } \\
\text { prevalence of poverty } \\
\text { amongst disabled } \\
\text { headed households }\end{array}$ \\
\hline $\begin{array}{l}\text { Dhungana, } \\
2006\end{array}$ & $\begin{array}{l}\text { Qualitative } \\
\text { study }\end{array}$ & Nepal & $\begin{array}{l}30 \text { women with } \\
\text { disabilities } \\
\text { (physical) }\end{array}$ & $\begin{array}{l}\text { Explores lives of } \\
\text { disabled women and } \\
\text { how external factors } \\
\text { (e.g. poverty) puts } \\
\text { them in dire poverty }\end{array}$ \\
\hline $\begin{array}{l}\text { dos Santos- } \\
\text { Zingale, } 2006\end{array}$ & $\begin{array}{l}\text { Qualitative } \\
\text { study }\end{array}$ & Sierra Leone & $\begin{array}{l}19 \text { adults (10 living } \\
\text { in segregated } \\
\text { community for } \\
\text { disabled; } 9 \text { living in } \\
\text { Makeni (integrated } \\
\text { community) }\end{array}$ & $\begin{array}{l}\text { Describes experience } \\
\text { of people with a } \\
\text { mobility disability when } \\
\text { fleeing conflict, settling } \\
\text { in temporary camps } \\
\text { and resettling in their } \\
\text { communities }\end{array}$ \\
\hline Gureje, 2006 & $\begin{array}{l}\text { Cross- } \\
\text { sectional } \\
\text { survey }\end{array}$ & $\begin{array}{l}\text { Yoruba- } \\
\text { speaking areas } \\
\text { of Nigeria }\end{array}$ & $\begin{array}{l}2152 \text { adults, } \\
>65 y r s ; 52.5 \% \\
\text { men, } 47.5 \% \text { women }\end{array}$ & $\begin{array}{l}\text { Estimate of disability in } \\
\text { a sample of older } \\
\text { adults; information } \\
\text { about } \\
\text { sociodemographic } \\
\text { correlates of disability }\end{array}$ \\
\hline
\end{tabular}




\begin{tabular}{|c|c|c|c|c|}
\hline $\begin{array}{l}\text { First Author } \\
\text { and Date }\end{array}$ & Study Design & Setting & Sample details & Purpose \\
\hline Mitra, 2006 & $\begin{array}{l}\text { Cross- } \\
\text { sectional } \\
\text { survey }\end{array}$ & India & $\begin{array}{l}\text { Used data from } \\
\text { National Sample } \\
\text { Surveys from } 2001 \\
\text { and } 2002 \text { (15-64 } \\
\text { year old people } \\
\text { only) }\end{array}$ & $\begin{array}{l}\text { The extent to which } \\
\text { people with disabilities } \\
\text { are employed in India; } \\
\text { characteristics of } \\
\text { disabled workers }\end{array}$ \\
\hline Filmer, 2008 & $\begin{array}{l}\text { Descriptive } \\
\text { study-survey }\end{array}$ & $\begin{array}{l}\text { Survey data } \\
\text { from Bolivia, } \\
\text { Cambodia, } \\
\text { Chad, } \\
\text { Colombia, India, } \\
\text { Jamaica, } \\
\text { Romania, } \\
\text { Burundi, } \\
\text { Mongolia, } \\
\text { Indonesia, } \\
\text { Mozambique, } \\
\text { South Africa, } \\
\text { Zambia }\end{array}$ & $\begin{array}{l}\text { 14 household } \\
\text { surveys in } 13 \\
\text { countries (12 } \\
\text { developing, } 1 \\
\text { transition); between } \\
5000 \text { and } 25,000 \\
\text { households in each } \\
\text { study (more in India } \\
\text { and Indonesia) }\end{array}$ & $\begin{array}{l}\text { Review of existing } \\
\text { data on prevalence of } \\
\text { disability and its } \\
\text { association with } \\
\text { poverty and schooling } \\
\text { in } 12 \text { developing } \\
\text { countries and } 1 \\
\text { transition country }\end{array}$ \\
\hline Guerra, 2008 & $\begin{array}{l}\text { Cross- } \\
\text { sectional } \\
\text { survey }\end{array}$ & Brazil & $\begin{array}{l}2143 \text { men and } \\
\text { women >60yrs in } 7 \\
\text { cities taking part in } \\
\text { a large cross- } \\
\text { sectional survey }\end{array}$ & $\begin{array}{l}\text { To examine the life- } \\
\text { course, gender, and } \\
\text { ethnic inequalities in } \\
\text { ADL disabilities among } \\
\text { urban-dwelling, elderly } \\
\text { Brazilians }\end{array}$ \\
\hline Gururaj, 2008 & Cohort study & Bangalore, India & $\begin{array}{l}35 \text { with OCD, } 35 \\
\text { with schizophrenia }\end{array}$ & $\begin{array}{l}\text { Family burden, QOL } \\
\text { and disability in } \\
\text { patients with } \\
\text { schizophrenia } \\
\text { compared to those } \\
\text { with moderate OCD }\end{array}$ \\
\hline Loeb, 2008 & $\begin{array}{l}\text { Case-control } \\
\text { study }\end{array}$ & South Africa & $\begin{array}{l}475 \text { with disabilities } \\
\text { and } \sim 376 \text { control } \\
\text { households }\end{array}$ & $\begin{array}{l}\text { Comparison of people } \\
\text { with a disability and } \\
\text { non-disabled peers } \\
\text { with respect to some } \\
\text { key poverty indicators. }\end{array}$ \\
\hline
\end{tabular}




\begin{tabular}{|c|c|c|c|c|}
\hline $\begin{array}{c}\text { First Author } \\
\text { and Date }\end{array}$ & Study Design & Setting & Sample details & Purpose \\
\hline Mitra, 2008 & $\begin{array}{l}\text { Cross- } \\
\text { sectional } \\
\text { survey }\end{array}$ & $\begin{array}{l}\text { Tamil Nadu, } \\
\text { India }\end{array}$ & $\begin{array}{l}652 \text { households } \\
\text { (disabled and non- } \\
\text { disabled) in } 15 \\
\text { villages in Tamil } \\
\text { Nadu; } 980 \text { non- } \\
\text { disabled men, } 262 \\
\text { disabled men }\end{array}$ & $\begin{array}{l}\text { Wage and } \\
\text { employment } \\
\text { differences of males } \\
\text { with and without } \\
\text { disabilities, using data } \\
\text { from village disability } \\
\text { survey in Tamil Nadu. }\end{array}$ \\
\hline $\begin{array}{l}\text { Rischewski, } \\
2008\end{array}$ & $\begin{array}{l}\text { Case-control } \\
\text { study }\end{array}$ & Rwanda & $\begin{array}{l}345 \text { cases and } 532 \\
\text { controls in urban } \\
\text { and rural settings }\end{array}$ & $\begin{array}{l}\text { Assess association } \\
\text { between poverty and } \\
\text { musculoskeletal } \\
\text { impairment in Rwanda }\end{array}$ \\
\hline $\begin{array}{l}\text { Schneider, } \\
2008\end{array}$ & $\begin{array}{l}\text { Qualitative } \\
\text { study }\end{array}$ & $\begin{array}{l}\text { Soweto, South } \\
\text { Africa }\end{array}$ & $\begin{array}{l}60 \text { women living } \\
\text { with rheumatoid } \\
\text { arthritis }\end{array}$ & $\begin{array}{l}\text { Personal and social } \\
\text { consequences of } \\
\text { rheumatoid arthritis in } \\
\text { women, living in } \\
\text { impoverished } \\
\text { conditions. }\end{array}$ \\
\hline $\begin{array}{l}\text { Braithwaite, } \\
2009\end{array}$ & $\begin{array}{l}\text { Descriptive } \\
\text { study (using } \\
\text { survey data) }\end{array}$ & $\begin{array}{l}\text { Vietnam and } \\
\text { Bosnia- } \\
\text { Herzegovina }\end{array}$ & Not specified & $\begin{array}{l}\text { application of } \\
\text { methodology } \\
\text { developed by Zaidi } \\
\text { and Burchardt (2005) } \\
\text { to assess the } \\
\text { additional costs of } \\
\text { living with a disability }\end{array}$ \\
\hline $\begin{array}{l}\text { Chatterjee, } \\
2009\end{array}$ & $\begin{array}{l}\text { Prospective } \\
\text { longitudinal }\end{array}$ & $\begin{array}{l}\text { Madhya } \\
\text { Pradesh, India }\end{array}$ & $\begin{array}{l}236 \text { people with } \\
\text { psychotic disorders } \\
\text { (Schizophrenia, } \\
\text { bipolar and others) }\end{array}$ & $\begin{array}{l}\text { The uptake and impact } \\
\text { of a service using the } \\
\text { community based } \\
\text { rehabilitation } \\
\text { framework for people } \\
\text { with psychotic } \\
\text { disorders in a rural, } \\
\text { impoverished setting }\end{array}$ \\
\hline Kiani, 2009 & $\begin{array}{l}\text { Qualitative } \\
\text { study }\end{array}$ & $\begin{array}{l}\text { North-west } \\
\text { province, } \\
\text { Cameroon }\end{array}$ & $\begin{array}{l}24 \text { women with } \\
\text { disabilities in } 2 \\
\text { focus groups; } 12 \\
\text { semi-structured } \\
\text { interviews; women } \\
\text { aged between 20- } \\
58 y r s\end{array}$ & $\begin{array}{l}\text { Gap analysis of } \\
\text { issues faced by } \\
\text { women with disabilities } \\
\text { in North West province } \\
\text { of Cameroon }\end{array}$ \\
\hline
\end{tabular}




\begin{tabular}{|c|c|c|c|c|}
\hline $\begin{array}{c}\text { First Author } \\
\text { and Date }\end{array}$ & Study Design & Setting & Sample details & Purpose \\
\hline Mitra, 2009 & $\begin{array}{l}\text { Cross- } \\
\text { sectional } \\
\text { survey }\end{array}$ & $\begin{array}{l}\text { Uttar Pradesh, } \\
\text { India }\end{array}$ & $\begin{array}{l}15 \text { villages, } 706 \\
\text { households; rural } \\
\text { dwellers, disabled } \\
\text { and non-disabled } \\
\text { workers, disabled } \\
\text { men over-sampled }\end{array}$ & $\begin{array}{l}\text { Magnitude and } \\
\text { determinants of wage } \\
\text { differentials by } \\
\text { disability status in an } \\
\text { agrarian labour market } \\
\text { analysis in rural UP. }\end{array}$ \\
\hline Shrestha, 2009 & $\begin{array}{l}\text { Cohort study } \\
\text { (survey) }\end{array}$ & Nepal & $\begin{array}{l}19,210 \text { people in } \\
3397 \text { households; } \\
\text { all persons } \\
\text { belonging to self- } \\
\text { help groups in the } \\
\text { three geographical } \\
\text { areas of Nepal }\end{array}$ & $\begin{array}{l}\text { Survey on situation of } \\
\text { persons with } \\
\text { disabilities in Nepalese } \\
\text { communities, } \\
\text { undertaken as } \\
\text { precursor to } \\
\text { establishing } \\
\text { community disability } \\
\text { self-help groups. }\end{array}$ \\
\hline $\begin{array}{l}\text { Zunzunegui, } \\
2009\end{array}$ & $\begin{array}{l}\text { Cross- } \\
\text { sectional } \\
\text { survey }\end{array}$ & $\begin{array}{l}\text { LAC: Argentina, } \\
\text { Barbados, } \\
\text { Brazil, Chile, } \\
\text { Cuba, Mexico, } \\
\text { Uruguay }\end{array}$ & $\begin{array}{l}10,587 \text { people }>60 \\
\text { years interviewed } \\
\text { at home using } \\
\text { structured } \\
\text { questionnaire; } \\
\text { examined disability } \\
\text { in ADL and IADL, } \\
\text { among other health } \\
\text { factors }\end{array}$ & $\begin{array}{l}\text { Difference between } \\
\text { older men and women } \\
\text { in health status in } \\
\text { urban Latin America. } \\
\text { Paper examined } \\
\text { whether differences } \\
\text { were explained by } \\
\text { differential exposures } \\
\text { during the life course } \\
\text { and differential } \\
\text { vulnerability to these } \\
\text { exposures }\end{array}$ \\
\hline $\begin{array}{l}\text { Engelbrecht, } \\
2010\end{array}$ & $\begin{array}{l}\text { Qualitative } \\
\text { study }\end{array}$ & $\begin{array}{l}\text { Western Cape, } \\
\text { SA }\end{array}$ & $\begin{array}{l}5 \text { adults with } \\
\text { disabilities ( } 3 \\
\text { current employees } \\
\text { and } 2 \text { ex- } \\
\text { employees) of the } \\
\text { same organisation } \\
\text { where } 69 \% \text { of } \\
\text { employees are } \\
\text { people with } \\
\text { disabilities }\end{array}$ & $\begin{array}{l}\text { Explored the factors } \\
\text { which cause people } \\
\text { with disabilities to } \\
\text { remain in or leave } \\
\text { employment in the } \\
\text { open labour market. }\end{array}$ \\
\hline
\end{tabular}




\begin{tabular}{|c|c|c|c|c|}
\hline $\begin{array}{l}\text { First Author } \\
\text { and Date }\end{array}$ & Study Design & Setting & Sample details & Purpose \\
\hline Trani, in press & $\begin{array}{l}\text { Cohort study } \\
\text { (survey) }\end{array}$ & $\begin{array}{l}\text { Afghanistan and } \\
\text { Zambia }\end{array}$ & $\begin{array}{l}\text { Zambia:3488 } \\
\text { people (1845 } \\
\text { people with } \\
\text { disabilities, } 1643 \\
\text { controls); } \\
\text { Afghanistan:1544 } \\
\text { people ( } 641 \text { people } \\
\text { with disabilities, } \\
903 \text { controls); } \\
\text { adults between } 14 \\
\text { and } 65 \text { yrs, with an } \\
\text { over-representation } \\
\text { of adult men }\end{array}$ & $\begin{array}{l}\text { Data from household } \\
\text { disability surveys from } \\
\text { Afghanistan and } \\
\text { Zambia on } \\
\text { relationships between } \\
\text { disability and multiple } \\
\text { dimensions of poverty }\end{array}$ \\
\hline
\end{tabular}




\section{REFERENCES}

Atkinson, A., \& Bourguignon, F. (1982). The comparison of multidimensioned distributions of economic status. Econom Stud, 49, 183-201.

Barron, T., \& Ncube J.M. (2010) Poverty and Disability. London: Leonard Cheshire Disability.

Baskind, R., \& Birbeck, G. L. (2005). Epilepsy-associated stigma in sub-Saharan Africa: The social landscape of a disease. Epilepsy \& Behaviour, 7(1), 68-73.

Braithwaite, J., \& Mont, D. (2009). Disability and poverty: a survey of World Bank Poverty Assessments and implications. ALTER, European Journal of Disability Research, 3, 219-232.

Chatterjee, S., Pillai, A., Jain, S., Cohen, A., \& Patel, V. (2009). Outcomes of people with psychotic disorders in a community-based rehabilitation programme in rural India. British Journal of Psychiatry, 195(5), 433-439.

Cock, J. (1989). Life "Inside the Shell" A needs survey of spinal cord-injured wheelchair users in a black South African township. Disability Handicap and Society, 4(1), 3-20.

DESA.. Disability and the Millennium Development Goals: A Review of Disability Strategies for Inclusion in Millennium Development Goal Efforts. New York: UN Department of Social and Economic Affairs. http://www.un.org/disabilities/documents/mdgs_review_2010_technical_paper_advance_text.pdf

DFID. (2000). Disability, poverty, and development. London: DFID.

DFID (2007). How to Note: Working on Disability in Country Programmes. London: DFID.

Dhungana, B. M. (2006). The lives of disabled women in Nepal: vulnerability without support. Disability \& Society, 21(2), 133-146.

dos Santos-Zingale, M., \& McColl, M. A. (2006). Disability and participation in post-conflict situations: The case of Sierra Leone. Disability \& Society, 21(3), 243-257.

Elwan, A. (1999). Poverty and disability: A survey of the literature. Social Protection Discussion Paper Series. Washington, DC: World Bank.

Engelbrecht, M., \& Lorenzo, T. (2010). Exploring the tensions of sustaining economic empowerment of persons with disabilities through open labour market employment in the Cape Metropole. South African Journal of Occupational Therapy, 40(1), 8-12.

EPPI-Centre. (2007). EPPI-Centre methods for conducting systematic reviews. London: EPPI-Centre, Social Science Research Unit, Institute of Education, University of London.

Filmer, D. (2008). Disability, poverty, and schooling in developing countries: Results from 14 household surveys. World Bank Economic Review, 22(1), 141-163.

Grant, M. J., \& Booth, A. (2009). A typology of reviews: an analysis of 14 review types and associated methodologies. Health Info Libr J, 26, 91-108.

Greenhalgh, T., Potts, H. W. W., Wong, G., Bark, P., \& Swinglehurst, D. (2009). Tensions and paradoxes in electronic patient record research: a systematic literature review using the meta-narrative method. The Milbank Quarterly, 87(4), 729-788.

Greenhalgh, T., Robert, G., Macfarlane, F., Bate, P., Kyriakidou, O., \& Peacock, R. (2005). Storylines of research in diffusion of innovation: a meta-narrative approach to systematic review. Social Science \& Medicine, 61(2), 417-430.

Groce, N., Kett,M., Lang, R., Trani, JF.. (2011) Disability and Poverty: The Need for a more Nuanced Understanding of the Implications for Development Policy and Practice. Third World Quarterly. (in press)

GTZ. (2006). Policy Paper: http://www.gtz.de/de/dokumente/en-disability-and-development.pdf.

Gu D, Dupre ME, Warner DF, Zeng Y. (2009) Changing health status and health expectancies among older adults in China: gender differences from 1992 to 2002. Social Science and Medicine. Jun;68(12):2170-9.

Guerra, R. O., Alvarado, B. E., \& Zunzunegui, M. V. (2008). Life course, gender and ethnic inequalities in functional disability in a Brazilian urban elderly population. Aging Clinical \& Experimental Research, 20(1), 53-61.

Gureje, O., \& Bamidele, R. (1999). Thirteen-year social outcome among Nigerian outpatients with schizophrenia. Social Psychiatry And Psychiatric Epidemiology, 34(3), 147-151.

Gureje, O., Ogunniyi, A., Kola, L., \& Afolabi, E. (2006). Functional disability in elderly Nigerians: results from the Ibadan study of aging. Journal Of The American Geriatrics Society, 54(11), 1784-1789.

Gururaj, G. P., Bada Math, S., Reddy, J. Y. C., \& Chandrashekar, C. R. (2008). Family burden, quality of life and disability in obsessive compulsive disorder: an Indian perspective. Journal Of Postgraduate Medicine, 54(2), 91-97.

Hoogeven, J. (2005). Measuring welfare for small but vulnerable groups: Poverty and disability in Uganda. J Afr Econ, 14, 603-631. 
Jang SN, Cho SI, Kawachi I. (2010) Is socioeconomic disparity in disability improving among Korean elders? Social Science and Medicine. 71(2):282-7.

JICA Sector Strategy Development Department. (2006). http://www.jica.go.jp/english/operations/thematic_issues/social/overview.html.

Khan, N. Z., Ferdous, S., Munir, S., Huq, S., \& McConachie, H. (1998). Mortality of urban and rural young children with cerebral palsy in Bangladesh. Dev Med Child Neurol, 40(11), 749-753.

Kiani, S. (2009). Women with disabilities in the north west province of Cameroon: resilient and deserving of greater attention. Disability and Society, 24(4), 517-531.

Kolm, S. C. (1977). Multidimensional egalitarianisms. Quart J Econom, 91, 1-13.

Liang J, Wang CN, Xu X, Hsu HC, Lin HS, Lin YH. (2010) Trajectory of functional status among older Taiwanese: Gender and age variations. Social Science and Medicine. 71(6):1208-17.

Loeb, M., Eide, A. H., Jelsma, J., ka Toni, M., \& Maart, S. (2008). Poverty and disability in Eastern and Western Cape Provinces, South Africa. Disability \& Society, 23(4), 311-321.

Maasoumi, E. (1986). The measurement and decomposition of multidimensional inequality. Econometrica, $54,771-779$.

Mitra, S. (2006). The capability approach and disability. Journal of Disability Policy Studies, 16(4), 236-247.

Mitra, S., \& Sambamoorthi, U. (2006). Employment of persons with disabilities: evidence from the national sample survey. Economic and Political Weekly, 41(3), 199-203.

Mitra, S., \& Sambamoorthi, U. (2008). Disability and the rural labor market in India: evidence for males in Tamil Nadu. World Development, 36(5), 943-952.

Mitra, S., \& Sambamoorthi, U. (2009). Wage differential by disability status in an agrarian labor market in India. Applied Economics Letters, 16(14), 1393-1398.

Mobarak, R., Khan, N. Z., Munir, S., Zaman, S. S., \& McConachie, H. (2000). Predictors of stress in mothers of children with cerebral palsy in Bangladesh. Journal of Pediatric Psychology, 25(6), 427-433.

Natale, J. E., Joseph, J. G., Bergen, R., Thulasiraj, R. D., \& Rahmathullah, L. (1992). Prevalence of childhood disability in a southern Indian city: independent effect of small differences in social status. International Journal of Epidemiology, 21(2), 367-372.

Oliver, M. (1996). Understanding Disability: From Theory to Practice. Basingstoke: Macmillan.

Ravallion, M., Chen, S., \& Sangraula, P. (2009). Dollar a day revisited. World Bank Econ Rev, 23(2), 163184.

Rischewski, D., Kuper, H., Atijosan, O., Simms, V., Jofret-Bonet, M., Foster, A., et al. (2008). Poverty and musculoskeletal impairment in Rwanda. Transactions Of The Royal Society Of Tropical Medicine And Hygiene, 102(6), 608-617.

Schneider, M., Manabile, E., \& Tikly, M. (2008). Social aspects of living with rheumatoid arthritis: a qualitative descriptive study in Soweto, South Africa - a low resource context. Health \& Quality of Life Outcomes, 6, 54-54.

Sen, A. K. (1992). Inequality Re-examined Oxford: Clarendon Press.

Shakespeare, T. (2001). The social model of disability: an outdated methodology? . In B. M. Altman \& S. N. Barnatt (Eds.), Exploring Theories and Expanding Methodologies: Where We Are and Where We Need To Go pp. 9-28). Oxford: Elsevier Science Ltd.

Shrestha, S., Shrestha, N. K., \& Deepak, S. (2009). A community assessment of poverty and disability among specific rural population groups in Nepal. Asia Pacific Disability Rehabilitation Journal, 20(1), 8398.

Strauss, M. (2007). Process explaing the concealment and distortion of evidence on gender symmetry in partner violence. Durham, New Hampshire: Family Research Laboratory, University of New Hampshire.

Streeten, P. (1981). First Things First: Meeting Basic Human Needs in Developing Countries. New York: Oxford University Press.

Swedish International Development Agency (SIDA). Rehab Lanka Project: http://www.sida.se/English/Partners/Civil-Society-/Results-of-Sidas-civil-society-cooperation/Making-adifference-/Economic-development/.

Terzi, L. (2004). The social model of disability: A philosophical critique. Journal of Applied Philosophy, $21(2), 141-157$.

Thomas, P. (2005). Disability, Poverty and the Millennium Development Goals: Relevance, Challenges and Opportunities for DFID. London: DIFD.

Trani JF, Bakhshi P, Noor AA, Lopez D, Mashkoor A.(2010) Poverty, vulnerability, and provision of healthcare in Afghanistan. Social Science and Medicine. Jun;70(11):1745-55

Trani, J.-F., \& Loeb, M. (2011). Poverty and disability: a vicious circle? Evidence from Afghanistan and Zambia. Journal of International Development.

Tsui, K. Y. (1995). Multidimensional generalizations of the relative and absolute indices: the AtkinsonKolm-Sen approach. J Econom Theory, 67, 251-265.

United Nations. (2006). Convention on the Rights of Persons with Disabilities. United Nations, The

United Nations. (2009) Realizing the Millennium Development Goals for Persons with Disabilities (A/RES/64/131). New York: United Nations General Assembly.. 
United Nations Development Programme. (2010). Human Development Report. The Real Wealth of Nations: Pathways to Human Development. Geneva: United Nations.

US Agency for International Development (US AID). http://www.usaid.gov/about_usaid/disability/.

Wolfensohn, J. (Dec. 3, 2002). Op-Ed Column. The Washington Post.

World Bank (1990). World Development Report. Washington, DC: The World Bank.

World Health Organization (2001). International Classification of Functioning, Disability and Health (ICF). Geneva: World Health Organization.

World Health Organization. (2010) Community-Based Rehabilitation: CBR Gidelines. Geneva: WHO.

World Health Organization/ World Bank (2011) World Report on Disability. Gevena: WHO; The World Bank.

Yousafzai, A. K., Pagedar, S., Wirz, S., \& Filteau, S. (2003). Beliefs about feeding practices and nutrition for children with disabilities among families in Dharavi, Mumbai. International Journal of Rehabilitation Research, 26(1), 33-41.

Zimmer Z. (2008) Poverty, wealth inequality and health among older adults in rural Cambodia. Soc Sci Med. 2008 Jan;66(1):57-71

Zunzunegui, M. V., Alvarado, B., Béland, F., \& Vissandjee, B. (2009). Explaining health differences between men and women in later life: a cross-city comparison in Latin America and the Caribbean. Social Science \& Medicine, 68(2), 235-242. 